\title{
On Catherine's Self-alienation in Wuthering Heights
}

\author{
Hao Sun \\ Huanghe Science \& Techonoloy College \\ Zhengzhou, China
}

\begin{abstract}
The thesis attempts to sort out and analyze Catherine's self-alienation process based on Marx's and Fromm's self-alienation theory, and reveal the essence of life.
\end{abstract}

Keywords-Wuthering Heights; Catherine; self-alienation; natural self; false self; self return

\section{INTRODUCTION}

Emily Bronte is a famous poetess and novelist in the 19th century in England, and a great genius in English literature history. Wuthering Heights, her only and romantic masterpiece, establishes her immortal status in English literature history as well as that of the world, and has aroused considerable controversy since it was published. For more than 150 years, many scholars and the literary critics at home and abroad have made massive comments and interpretations on the work from various angles, including feminism, Gothic style, ecologism, narrative techniques, etc. However, selfalienation theory has seldom been adopted in related studies. Hence, the thesis attempts to sort out and analyze Catherine's self-alienation process based on Marx's and Fromm's selfalienation theory, and reveal the essence of life.

\section{SELF-ALIENATION THEORY}

Many scholars and philosophers have studied and developed alienation theory, and some researches are related to self-alienation, however, until 1844, the concept of selfalienation was put forward by Marx. From Marx, the alienated relationship between man and himself is selfalienation which is the loss of self-identity which can be understood as self-estrangement to some degree; and it is man's alienation from his nature. Fromm advanced alienation and began to focus on people's alienation from themselves. For Fromm believed that alienation was a kind of psychological experience, a mode of experience and it was the tragedy of human beings' existing conflicts ( $\mathrm{Li}$ Dianlai 2001:187). Self-alienation has connotation that the force which is alien with man makes him lose selfhood and his essence, his subjectivity, his freedom, his personality, and becoming inhuman. As a result, human beings are subjected to the inhuman power against himself, lose freedom and lose selfhood at the same time.

Self-alienation focuses on the three key concepts of natural self, false self and self return in the thesis. Actually, self-alienation originates from philosophy and is characterized by one's self split. The process of selfalienation consists of natural self, false self and self return.
Among them, natural self is a real self and one is true to himself; False self is who betrays or restrains one's natural self under stress and loses himself at last; self return is who regains natural self when one suffers a lot and comes to realize he has lost himself and decides to restore his natural self.

Actually, the theme of alienation from the self frequently appears in the western literature. Sometimes we lose self and can not tell who I am and who is real, as Catherine's natural self in Wuthering Heights is far away from pretended herself in vanity. Therefore, she feels powerless facing worldly fame and wealth and suffers a tragic destiny in self-alienation. Here in my thesis, it will conclude that Catherine will experience the painful process from natural self to false self in self-alienation, and that the pain and split of false self make him long to return to his natural self.

\section{CATHERINE'S NATURAL SELF}

Before we study the theme of Catherine's self-alienation, it is essential for us to know her original and true self. A man's original nature is pure and true without artificiality in behavior and bias in mind. In Wuthering Heights, Catherine is originally such a pure and true girl, who always behaves naturally and thinks simply regardless of worldly courtesies and bias. According to Fromm: "character in the dynamic sense of analytic psychology is the specific form in which human energy is shaped by the dynamic adaptation of human needs to the particular mode of existence of a given society" (Fromm, 2002:239)

In Wuthering Heights, as Catherine grows up in the wild environment of the Heights, which shapes her nature of wildness, which is performed in her daily wild behavior, her rebellion against constraints on her wildness as well as her complex to the wilderness of nature. Catherine spends her childhood in the desolate moors where she is near nature but far from the world. She seeks out her valuable natural self in the peculiar environment, Catherine is filled with true power and wild and primitive instinct. In the novel, Catherine conveys an impression of a mischievous, wayward, wild, and wicked girl. But Catherine is a kind and lively girl. She means no harm, for "when she made you cry in good earnest, it seldom happened that she would not keep you company, and oblige you to be quiet that you might comfort her." (Bronte, 1996:29) She usually defies others with her bold, saucy look, and her ready words; turns Joseph's religious curses into ridicule, however, because of her bonniest eye, sweetest smile, and lightest foot in the parish, one can not 
help forgiving her instead of being annoyed with her. She has great interest in making you cry without harm, her wild and wicked personality is formed under the spoiling. She loves nature and shows a strong desire for freedom. Her greatest happiness is roaming and playing freely on the moors all day with Heathcliff. Catherine is glamorous and lively, she is always full of beans, Catherine's high spirits indicate that she is always very happy and displays her dispositions naturally and freely without artificial oppression or control. That's why she is always high in spirit and impresses her people with such impressions of wildness, naughtiness and disobedience, all of which are dispositions against worldly courtesies of politeness, elegance and obedience and reflect her natural, original and true self as well as her spiritual happiness and freedom.

Catherine is wild and rebellious. Her nature and natural self are reflected in her rebellion against constraints imposed on her wildness, to some degree, when her mother dies, her father withdraws from the children in grief. Catherine almost suffers the bereavement. Nelly relates the attempts to improve his daughter, or tame her result only in failures, Catherine is always rebelling them with her fearless, daring, ruthless and impertinent look. She mocks at Joseph's (the servant) religious curses into ridicule, she is always teasing me with her ready words and doing just what her father hates most. After behaving as badly as possible all day, sometimes she comes fondling to make it up at night. The old father would tell her that he will not love her and make her say thy prayers to ask God's pardon. Her father talks to her that her mother and he must hate that we have give a birth to her and raise her, which makes her cry at first; and then, being complained by her father repeatedly makes Catherine annoyed and tired. She will laugh if Nelly tells her to say she should say sorry for her faults and beg to be forgiven. Sometimes her father is too pleased to express her gentlesaying to her Cathy, and asks why she can not always be a good lady. And she turns her face to his, laughs, and responds that why cannot he always be a good man. From the narration, we know in her family there is no healthy narcissistic supply from mother, approximately the others. The father as others is equally out of touch with Catherine. None of Hindley, Joseph and Nelly takes such a responsibility to guide her. Though born in a rich, highsociety family, Catherine is not a lucky girl who enjoys the noble and happy childhood. After her father dies, Catherine is maltreated by her brother Hindley and gets a little warmth of the family. And she seldom feels love and warmth from the family, especially his brother, his brother is too cold to her and Catherine is also often punished by the family because of her wildness and naughtiness, she escapes or tries to escape from the punishment to the moors on the Heights, and she forgets the punishment the minute she is there. She becomes untamed and rebellious. She ignores religious rituals, at the same time she is willful, arrogant and rude. And family indulgence, environmental impact and her noble status make her stubborn and rebellious. Wuthering Heights has the same mood as Catherine. The setting accords with her intrinsic nature. Catherine, just like the place she lives in, has an opposite temperament. When growing, Catherine likes running in the roaring storm on the moors with bare feet, which helps to shape her character. That period of life leads to Catherine's instinctive rebellion, and lays a solid foundation for her character that looks like a hard and timeless rock. Catherine in particular, lives a wild and natural life, she has deep complex to wilderness.

In Wuthering Heights, When Catherine and Heathcliff are children they get along well with each other. They have the same nature. Catherine's self-identity is rightly built on Heathcliff, who grows up together with her and is as wild as her in nature. At the very beginning of the story, the tenant Mr. Lockwood discovers a Catherine's diary, in which there writes a name "Catherine Heathcliff" (Bronte, 1996:13). It is known that Catherine's full name should be "Catherine Earnshaw", but Catherine puts her name in the way as "Catherine Heathcliff", which shows that she considers herself as Heathcliff, a mind ever confesses herself to Mrs. Dean: My great miseries in this world have been Heathcliff's miseries, and I watched and felt from the beginning; my great thought in living is himself...I am Heathcliff---he is always in my mind---not as a pleasure, any more than I am always a pleasure to myself---but, as my own being... (Bronte, 1996:59).As Catherine builds her self-identity on Heathcliff, so Catherine has a natural love to Heathcliff which originates from her nature and can not be disrupted, which is demonstrated by her reaction to her brother Hindley's treatment of this attachment. However,Catherine, having been keeping intercourse with Edgar, decides to marry him when he proposes to her, because she announces that she loves him. However, unlike her love to Heathcliff, her love to Edgar is not natural but pretended. she is obsessed with worldly fame and wealth and decides to marry Edgar, the young master of the Grange, disrupting her attachment to Heathcliff and accordingly making her lose her natural love and self as well as her spiritual happiness and freedom, as will be analyzed in the following point.

\section{CATHERINE'S FALSE SELF}

Catherine has untamed and rebellious nature and she is borne for wilderness. However, we feel puzzled why she is alienated with herself and her nature. By analyzing Fromm's theory in The Fear of Freedom (2002) and The Sane Society (2002), it can be concluded that alienation is aroused and aggravated by social conditions and social character in a given society. As a mix of various contradictions, Catherine is a split being with two selves: a bright self and a dark self. Driven by these ambivalent thoughts or elements inside her, she becomes confused in finding his real self and his identity in the universe. Therefore, she becomes self-alienated under longtime of contradictions.

Catherine's change in nature begins from her return from Thrushcross Grange, and here she is tempted by the Lintons' way of life and temperance which are very different from hers in Wuthering Heights. After five weeks at the Thrushcross Grange where Catherine is well treated, educated, and her self-respect is raised with fine clothes and flattery, her new look gains high praise from so many people including Hindley who has never liked her since she has made a union with Heathcliff, It is described that after five weeks' stay in the Grange: 
- so that, instead of a wild, hatless little savage jumping into the house, and rushing to squeeze us all breathless, there lighted from a handsome black pony a very dignified person, with brown ringlets falling from the cover of a feathered beaver, and a long cloth habit, which she was obliged to hold up with both hands that she might sail in. (Bronte, 1996: 64)

Catherine's wild nature is concealed as she stays with the Lintons. Her brother sincerely praises she is a beauty and is like a lady. The praise extremely satisfies Catherine's vanity and she begins to prefer Edgar's refinement to Heathcliff's roughness. What is worst is that she starts to dislike and, cold-shoulder Heathcliff for his slovenliness and dirtiness. More contact with the Lintons makes Catherine closer to gentility; after her marriage, Catherine restrains herself to lead a quiet but depressive life under the husband's tolerance and care, while of which never brings any happiness to her. However she tries to enjoy Edgar's love, her inner world remains solitary. She enjoys wielding her power and tyrannizing Edgar and Isabella who give in to all her whim. Catherine is not happy any more by losing her self and gets trapped in a spiritual gloom in her latter life, which also reflects her pain and affliction in this sense. Or rather, pain of struggling between her true self and external obsession.After marriage, Catherine restrains herself to lead a quiet but depressive life under the husband's tolerance and care, while of which never brings any happiness to her. However she tries to enjoy Edgar's love, her inner world remains solitary. Erich Fromm tells us in an alienated situation. There is not much love or hate to be found in human relations of our day. There is, rather, a superficial friendliness, and a more than superficial fairness, but behind that surface is distance and indifference (Fromm, 1991:165). The point is well demonstrated in Wuthering Heights vividly:

- ... but when she was calm, there seemed unearthly beauty in the change. The flash of her eyes had been succeeded by a dreamy and melancholy softness; they no longer gave the impression of looking at the objects around her: they appeared always to gaze beyond and far beyond--you would have said out of this world. Then the paleness of her face--its haggard aspect having vanished as she recovered flesh--and the peculiar expression arising from her mental state, though painfully suggestive of their causes, added to the touching interest which she awakened; and-invariably to me, I know, and to any person who saw her, I should think--refuted more tangible proofs of convalescence, and stamped her as one doomed to decay. (Bronte, 1996:113)

The comfortable life can not make up for her mental emptiness. In her better moods, she endures Mr. Linton's efforts dispassionately, only showing their uselessness by now and then suppressing a weary sigh, and checking him at last with the saddest of smiles and kisses; at other times, she will lose her temper and turn away, and hide her face in her hands, or even push him off angrily. They were in different worlds, In fact, in Catherine's inner most heart, she scorns Edgar's civility as a weak nature and can not bear his philosophical obedience of submitting to external constraints.
After they get married, when Edgar wants to express his discontent with Catherine's attachment to Heathcliff, he chooses to do it in indirect ways, for example, making himself immersed in his books and keeping silence to Catherine, which arouses Catherine's anger and quarrels with him. She scolds him of his cold blood that he can not understand her and console her in mind, and she thinks that Edgar's feelings are like ice-water, but hers are boiling, and the sight of his chillness and coldness makes her angry and distressed greatly, which shows that in her innermost heart, she can not bear and even hate Edgar's weak attitude of treating things with calmness and concession, for she is wild in nature and tends to outpour her true dispositions and emotions directly, and this means Catherine's love to Edgar does not originate from her nature and natural self.

In fact, Catherine is disturbed even wonders whether she is wrong or not to decide to marry Edgar: "'Here! And here!' replied Catherine, striking one hand on her forehead, and the other on her breast: 'in whichever place the soul lives. In my soul and in my heart, I'm convinced I'm wrong!'” (Bronte, 1996: 56) This confession shows that Catherine is clear in her innermost heart that her marrying Edgar will be a big mistake, for it is not Edgar but Heathcliff that she is spiritually attached to and shares the most happiness with, and marrying Edgar will be a betrayal of her natural love to Heathcliff and accordingly a betrayal of her natural, original and true self. Because of Catherine's betrayal of their love, Heathcliff leaves Wuthering Heights, on Heathcliff's departure, Catherine can not be persuaded into being calm and keeps hanging about to and fro and shouting from time to time. Actually, it is not merely Heathcliff that is gone; rather, it is Catherine's natural, original and true self that is gone, and gone with Heathcliff, on whom her sense of self is built and to whom her spiritual happiness is attached, so Catherine's unease and extreme emotional disturbance at Heathcliff's departure reflects her pain of losing her self, a natural, simple and true self that is free from worldly courtesies and bias and easily gets pleased with a full expression of her nature and natural love.

As Catherine despises Heathcliff because of his humble social position and marrying him will be a shame to her family and to herself, Catherine decides to marry such Edgar who does not match her in nature at all. As a matter of fact, she desires to fill up her spiritual loss by material comfort and possession. Catherine's utilitarian choice in marriage seems reasonable and natural, but Catherine has to make the hard choice in that social environment. In Victoria period, men had a dominant position and women's status was very low. Only in marriage, female value could be reflected in a disadvantaged position, and the only standard for males' value was their wealth and position, but this became the female mate value. In that era, family status and wealth occupied the absolute advantage in marriage. Catherine is unable to choose her own marriage from her inner love. In nature, Catherine only loves Heathcliff to the death, and she has the most sincere love for Heathcliff. As a social man, It is reasonable for her to choose to marry Linton, because only in this way, she will be able to survive in the society, this is the actual choice for people in any society. 
For her, Heathcliff represents love, Linton, she is the foundation for survival, she can't leave behind and chooses Linton, Thrushcross, which embodies the prettier, more comfortable side of bourgeois life, seduces Catherine. Catherine's stay in Thrushcross Grange throws her into inner conflict by giving a new form to her search for glory, one that separate her from Heathcliff and forces her to repress some of the strongest components of her own personality. Instead of satisfying her pride through a spirited rebellion, she now craves the approval of Linton, who representing the conventional world.

\section{CATHERINE'S SELF RETURN}

In Wuthering Heights, Catherine comes to realize her wrong choice at the moment of her death, meanwhile, she makes a good dream that she returns to her beloved wilderness, her spiritual home, and dies peacefully, returning to her natural self and regaining her spiritual happiness and freedom. So she denies her false self and expects to discard worldly temptation to regain her natural happiness and freedom.

Marx states when one is involved in life predicaments: “... affirm himself but denies himself, does not feel content but unhappy, he does not develop freely his physical and mental energy but mortifies his body and ruins his mind."(Marx, 2002: 33) In Catherine's later life, she suffers life predicaments in dilemma and pain, and she falls in illness. When her energy is exhausted in the fruitless strain of revolt, death appears to be the only door of relief. When she is ill, Catherine tells her maid that by marrying Edgar, she has deserted herself by leaving Wuthering Heights and changed into Mrs. Linton, the wife of a man she doesn't love in nature, and she thinks that her marriage to Edgar is completely ridiculous, and that she has fallen far apart from her world, she ever says to Heathcliff that she and Heathcliff suffer the same great torment, and she wishes them never to be separated. She feels very sad and sorry for him and they have the distress even she lives in the civilized place, which is like a shaking prison and irks her most. So she is exhausted and very tired of being enclosed there. She is too weary to escape from that glorious world, and she wants to leave the place and returns to her beloved wilderness with singing birds and fresh air. But in the glorious world, she feels lonely and alienated, in fact, she knows she doesn't belong to Thrushcross that is admired by previous her self. Here, she feels deep regret for her wrong choice, and she traps herself in anguish. Now, she is a mixture that interweaves her natural self and false self, which makes her in predicaments of struggling between her nature and worldly constraints, bias and fame and wealth. Hence, when she is seriously ill, she longs to be the carefree and wild girl again, who can be brave enough to cry, laugh, rebel and love at her will, and who is natural and free enough to play in her beloved wilderness, that is, not to be disturbed by external things of worldly courtesies, bias, fame and wealth, the wish not only further indicates Catherine's desire to discard worldly constraints and confinement, but also shows that she longs to return to have her natural happiness and expose her true dispositions and emotions freely. Evidently, Catherine is giving up her false self by denying her love to Edgar based on worldly fame and wealth. When she gets obsessed with worldly fame and wealth, so she decides to marry the other man she does not really love to fulfill her vanity for superficial glory. Nevertheless, tortured by a tragic marriage, she comes to realizes that her choice is a big mistake, and she gets to understand that once she loses her simplicity and trueness to external obsession with superficial glory of worldly fame and wealth, Catherine enjoys a spiritual peace in her death. At the same time, Catherine makes a confession to her beloved Heathcliff at the last moment of her life, She tells him that she feels very sorry to hurt him by choosing the man she does not really love and wishes they would be together forever and regain their previous happiness of running freely in the wilderness of the Heights, which endows them with innocence and free spirit and which is their final resort where they can recall the good old days together, and she pleads for his forgiveness and tells him that he has already been in her soul and will be taken along with her if she leaves this world.

Fortunately, at the last moment of her life, she gets beyond external constraints and obsessions, returns to her natural self in her mind and regains her spiritual happiness and freedom, so she dies in peace, calmness and tranquility.

Based on the above analysis and discussion, it is concluded that Marx's and Fromm's self-alienation theory indicates that one will experience the painful process from natural self to false self in self-alienation, and that the pain and split of false self make him long to return to his natural self. The theme the thesis is about Catherine's self-alienation in Wuthering Heights, which makes us know her selfalienation is not only an existential predicament, but a spiritual one. Fortunately, she comes to realize her wrong choice after her false self, and returns to her natural self. As a matter of fact, her self-alienation is the reflection of men's common predicament in their existence, that is, she loses herself to external things, and is involved in isolation, even in death, and eventually death makes her return to her natural self and find the final spiritual home. However, Death is not only way for people in self-alienation to return to their natural self. When people want to fight against selfalienation effectively, they must resist external temptation to keep their natural self, which demands they have an invincible will. If people are powerful enough to get beyond external constraints, they can keep their natural self.

\section{REFERENCES}

[1] Bronte, Emily. Wuthering Heights. Beijing: the Foreign Languages Press, 1996.

[2] Fromm, Erich. The Sane Society. NewYork: Fawcett Publications, 1966.

[3] Gao Jihai. A Study of Wuthering Heights from the Perspective of Theme and Narratology.Foreign Literature Research,2008(3).

[4] Marx, Engels. The Collection of Marx and Engels. Volume 3. Beijing: People's Publishing House, 2002 